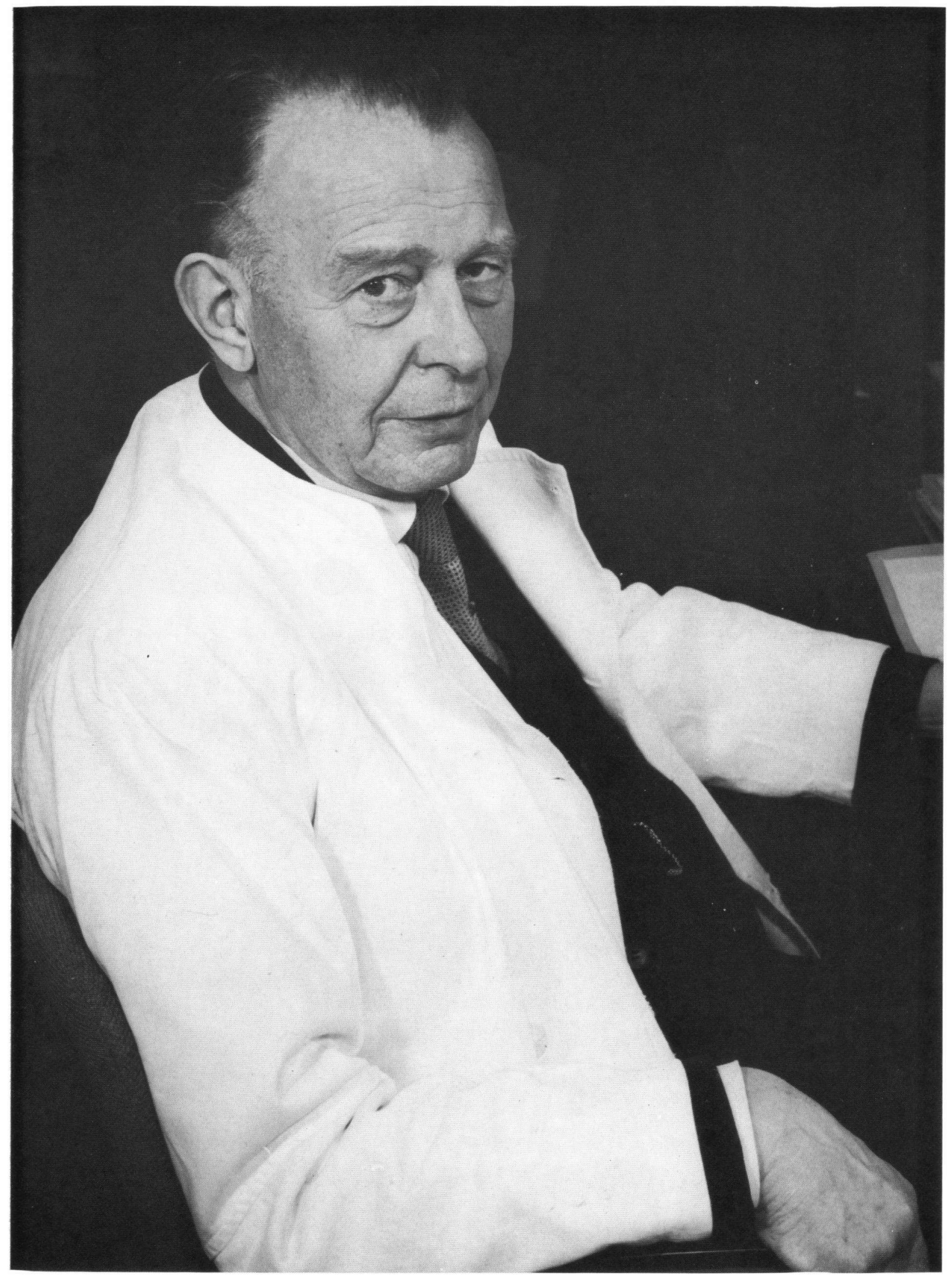

PHOTO: L. R, HAFKAMP 


\title{
HENDRIK ENGEL 70 JAAR
}

door

\author{
L. F. DE BEAUFORT
}

Bij een bezoek van Koningin Wilhelmina aan het Zoölogisch Museum van Amsterdam vroeg H.M. aan de conservator Dr. Engel wat zijn specialiteiten waren en kreeg ten antwoord: "Naaktslakken en Stekelhuidigen". Volgens Engel had de Koningin moeite ernstig te blijven kijken.

$\mathrm{Nu}$ mij gevraagd is bij zijn afscheid als hoogleraar en directeur van het Zoölogisch Museum het wetenschappelijk werk van Engel te bespreken, zal ik niet beginnen met te vermelden: de specialist in Nudibranchia en Echinodermen. Zeker, die groepen hebben met succes zijn belangstelling gehad, maar het spreekt van zelf dat iemand die voor zijn candidaatsexamen als bijvakken had gekozen: "erfelijkheidsleer en wijsbegeerte" nog wel wat anders in zijn mars had. En dan komt nog niet eens naar voren: de geschiedenis van de zoölogie, eerst door hem als privaat-docent gedoceerd en later in zijn leeropdracht als hoogleraar afzonderlijk genoemd, een tak der zoölogie die steeds zijn bijzondere interesse heeft gehad.

Behalve deze zuiver wetenschappelijke taken heeft Engel echter als directeur van het Zoölogisch Museum nog meer op zijn schouders gekregen en dat was lang niet altijd de meest aangename taak. Het directeurschap van het Amsterdamse Zoölogisch Museum is van de eerste directeur af, Prof. Max Weber, met veel tegenslagen en moeite gepaard gegaan.

Toen Prof. Weber de zoölogische collecties van Artis en de Universiteit te beheren kreeg waren deze in volstrekt onvoldoende ruimten ondergebracht. In 1914 kwam een plan gereed voor de bouw van een Zoölogisch Museum, maar door de oorlog kon er van uitvoering niets komen. Toen ik in 1922 het directeurschap overnam begon ik opnieuw, maar aan alle plannen werd door de crisis van 1933 en de 2 de wereldoorlog de bodem ingeslagen. Toen Engel mij opvolgde was de horizon weer wat opgeklaard en vol moed vatte de nieuwe directeur de pogingen tot sanering van de toestand op. Voorlopig kon dat alleen bestaan in verbetering van de gebouwen en het is dan ook Engel gelukt daarin veel te bereiken. De verbeterde berging van het niet voor het publiek toegankelijke materiaal, de zorg en bewerking der collecties door spectaculaire uitbreiding van het aantal conservatoren en de inrichting van de museumzalen in het aquariumgebouw voor telkens varieerende belangrijke tentoonstellingen, dat alles was zijn werk.

Maar ondertussen werd "het grote plan", de bouw van een nieuw museum, niet vergeten. Het kwam zelfs zover, dat alle plannen gereed kwamen en slechts gewacht werd op het sein, waarop men de bouw zou kunnen beginnen. Maar om redenen waarop hier niet verder zal worden ingegaan, kwam er weer uitstel. Al zal dan ook het nieuwe museumgebouw niet meer onder Engel's directeurschap gebouwd worden, toch zal de uitvoering van "het plan Engel" hem de eer geven, die hem toekomt.

NOTE. A biography and a selected bibliography of Prof. Dr. H. Engel are published in Beaufortia 15 (1968) by W. S. S. van Benthem Jutting (nr. 179, pp. 1-5) and Bauke van der Veen (nr. 180, pp. 7-14) respectively. 